\title{
Review: Photocatalytic effects of titanium dioxide nanoparticles on aquatic organisms - current knowledge and suggestions for future research
}

Authors: Vena N. Haynes ${ }^{1 *}$, J. Evan Ward ${ }^{1}$, Brandon J. Russell ${ }^{1}$, Alexander G. $\operatorname{Agrios}^{2}$ 


\section{Review: Photocatalytic effects of titanium dioxide nanoparticles on aquatic}

\section{organisms - current knowledge and suggestions for future research}

Nanoparticles are entering natural systems through product usage, industrial waste and postconsumer material degradation. As the production of nanoparticles is expected to increase in the next decade, so too are predicted environmental loads. Engineered metal-oxide nanomaterials, such as titanium dioxide, are known for their photocatalytic capabilities. When these nanoparticles are exposed to ultraviolet radiation in the environment, however, they can produce radicals that are harmful to aquatic organisms. There have been a number of studies that have reported the toxicity of titanium dioxide nanoparticles in the absence of light. An increasing number of studies are assessing the interactive effects of nanoparticles and ultraviolet light. However, most of these studies neglect environmentally-relevant experimental conditions. For example, researchers are using nanoparticle concentrations and light intensities that are too high for natural systems, and are ignoring water constituents that can alter the light field. The purpose of this review is to summarize the current knowledge of the photocatalytic effects of $\mathrm{TiO}_{2}$ nanoparticles on aquatic organisms, discuss the limitations of these studies, and outline environmentally-relevant factors that need to be considered in future experiments.

Keywords: nanoparticles; photocatalytic; aquatic organisms; UV; titanium dioxide 


\section{Introduction}

Manufactured titanium dioxide $\left(\mathrm{TiO}_{2}\right)$ nanoparticles $(\mathrm{NP} ; 1-100 \mathrm{~nm})$ are extensively used in

41 industrial and consumer goods, including sunscreens, personal care products, solar cells, and

42 food (Galley \& Fardell 1997; Canesi et al. 2010; Clemente et al. 2014; Weir et al. 2012). As the

43 production of $\mathrm{TiO}_{2}$ and its use in consumer products increases, so too does the likelihood of

44 release into the environment as a result of spills, use of products, or post-consumer degradation

45 of material. Predicted environmental concentrations of $\mathrm{TiO}_{2} \mathrm{NP}$ in water are on the order of ppb

46 (Mueller \& Nowack 2008; Gottschalk et al. 2011), with expected environmental loads as high as

$472,000,000$ to $6,000,000$ tons in the next 10 years (Robichaud et al. 2009). The accumulation of

48 NP in the environment is likely to be non-uniform (e.g., Gottschalk et al. 2011), with higher

49 concentrations in near-shore waters which are more impacted by run-off, wastewater discharge,

50 and proximity to human populations. $\mathrm{TiO}_{2} \mathrm{NP}$ concentrations of $1-100 \mathrm{mg} / \mathrm{L}$ are known to have

51 deleterious effects on fish and invertebrates (Blaise et al. 2008). Thus, there is a need to

52 understand the environmental impact of these NP.

53 The photocatalytic properties of metal oxide $\mathrm{NP}$ (e.g., $\mathrm{TiO}_{2}, \mathrm{CeO}_{2}$ and $\mathrm{ZnO}$ ) are well known

54 (Wold 1993; Matsuo et al. 2001; Ma et al. 2013), and $\mathrm{TiO}_{2}$ NP have been exploited in a wide

55 range of photocatalytic applications including coated nanocomposites in sunscreens for

56 ultraviolet (UV) protection and in 'green' technology cements that actively purify the air of

57 pollutants (Galley \& Fardell 1997; Torrey 2014). In aqueous media, $\mathrm{TiO}_{2} \mathrm{NP}$ can produce

58 radicals when activated by UV light (see below). The radicals, in turn, can damage microbes and

59 provide an antimicrobial property that has been utilized by medical, food and water-treatment

60 industries (Rai \& Bai 2011). In fact, most previous reports regarding the effects of photoactive

$61 \mathrm{TiO}_{2}$ nanoparticles on bacteria have focused on methods to eliminate microbes from drinking 
62 water (e.g., Maness et al. 1999, Cho et al. 2004, Rincón \& Pulgarin 2003), a topic that will not be 63 covered in this review.

64 Although the beneficial application of $\mathrm{TiO}_{2}$ is clear, such photoactivity can have

65 ecotoxicological implications when these NP enter natural systems. Understanding the combined 66 effects of $\mathrm{TiO}_{2} \mathrm{NP}$ and UV light on aquatic organisms under environmentally relevant conditions 67 is critical, but data demonstrating such effects are sparse. Many studies used $\mathrm{TiO}_{2}$ concentrations 68 above those deemed environmentally relevant ( $\geq 10 \mathrm{ppm}$ to ppt, or coated surfaces), cultured 69 bacteria, and/or UV exposure levels 2 to 10 times higher than those found in the photic zone of 70 most near-shore waters (e.g., Rincón \& Pulgarin 2003; Benabbou et al. 2007; Alrousan et al. 71 2009; Chorianopoulos et al. 2011; Dhandapani et al. 2012). For example, Ma et al. (2012) 72 exposed water fleas to NP concentrations above those deemed environmentally relevant ( $2 \mathrm{~g} / \mathrm{l})$, 73 and Reeves et al. (2008) exposed goldfish skin cells to UVA (340-420 nm; 0.007-0.03 mW/ $\left.\mathrm{cm}^{2}\right)$ 74 for 2 hours, a light duration and dose that highly underestimates natural conditions. Some 75 potential photocatalytic effects have been demonstrated under environmentally relevant 76 conditions. Faria et al. (2014) exposed zebrafish embryos to full-spectrum light (280-800 nm; $77 \quad 1.5-4.5 \mathrm{~mW} / \mathrm{cm}^{2}$ ) and $1 \mathrm{mg} / \mathrm{L} \mathrm{NP}$, resulting in reactive oxygen species (ROS) production and 78 oxidative stress.

79 Whereas only a few aquatic organisms have been investigated to date, and most studies have 80 been performed on model organisms in order to streamline high-throughput toxicity tests, there is 81 growing interest in the impact of photoactive NP in aquatic environments. Thus, in this review, 82 we summarize current knowledge of the photocatalytic effects of $\mathrm{TiO}_{2}$ on aquatic organisms, 83 discuss the limitations of these studies, and outline the experimental and environmental factors 84 that need to be considered in future experiments (e.g. organic matter, marine snow, light levels). 
85 In exploring the photoactive effects of metal-oxide NP on aquatic organisms, it is crucial that

86 experimental conditions are standardized and environmental parameters defined so that a more

87 accurate understanding of potential impacts can be obtained.

\section{Photocatalytic reactions in aqueous media}

An understanding of the photophysics and photochemistry of $\mathrm{TiO}_{2}$ in water is essential in predicting not only the effects of $\mathrm{TiO}_{2}$ on aquatic systems, but also how aqueous constituents affect the photocatalytic processes. $\mathrm{TiO}_{2}$ is a semiconductor, which implies two critical properties (Mills \& Le Hunte 1997). First, the wave-functions of the constituent atoms interact with each other over long distances. This means that instead of atomic orbitals combining to form discrete molecular orbitals, as when atoms combine to form molecules, atomic orbitals combine throughout an entire crystal to form bands (see Figure 1). Second, as the bands are populated from low to high energy with the electrons provided by the $\mathrm{Ti}$ and $\mathrm{O}$ atoms, the last electrons added exactly fill one band. This highest-energy filled band, the valence band, is akin to the highest occupied molecular orbital (HOMO) of a molecule. A bandgap $\left(\mathrm{E}_{\mathrm{g}}\right)$ separates the top of the valence band from the bottom of the conduction band, the lowest unfilled band, which is akin to the lowest unoccupied molecular orbital (LUMO) of a molecule. In a perfect semiconductor at $0 \mathrm{~K}$, the valence band would be completely filled and the conduction band completely empty. But $\mathrm{TiO}_{2}$ forms with a slight oxygen deficiency, which leaves a small permanent electron population in the conduction band.

A photon whose energy $(\mathrm{hv})$ is greater than or equal to $\mathrm{E}_{\mathrm{g}}$ can promote an electron from the valence band to the conduction band. This produces the charge separation that drives all subsequent chemistry, since the conduction band electron $\left(\mathrm{e}_{\mathrm{CB}}^{-}\right)$is at a very negative potential, making it strongly reducing, and the 'hole' left behind in the valence band $\left(\mathrm{h}_{\mathrm{VB}}^{+}\right)$is at a very 
positive potential, making it strongly oxidizing. Indeed, in principle they are capable of reducing water to $\mathrm{H}_{2}$ and oxidizing it to $\mathrm{O}_{2}$, although this is kinetically slow (Fujishima \& Honda 1972). The absorption-band cut-off for $\mathrm{TiO}_{2}$ varies with the specific crystalline form. For example, the rutile and anatase forms have band gaps of ca. 3.0 and $3.2 \mathrm{eV}$, corresponding to absorption-band cut-offs of 413 and 388 nm, respectively (Yang et al. 2004; Nakano et al. 2009). Doping with certain elements can change the band-gap width, causing a shift in the absorption edge wavelength (Asahi et al. 2001; Shirley et al. 2010).

Once an electron-hole pair has been formed by photoexcitation, there are three main possibilities for their immediate fate- (1) reaction: one or both charges react with molecules adsorbed to the surface; (2) recombination: the electron returns to the hole, generally dissipating the absorbed photon energy as heat; (3) trapping: one or both charges migrate to defect states in the material. By far the most frequent outcome is recombination: about $90 \%$ of electron-hole pairs formed by photoexcitation quickly recombine with no chemical effect (Serpone et al. 1995). Trapping reduces the energy available to the trapped charge, making it a somewhat weaker reductant or oxidant, but it also serves to spatially separate the two charges from each other, making recombination less likely (Hoffmann et al. 1995). A trapped charge can still be lost ultimately to recombination, but the trap state gives it more time to engage in a chemical reaction. Ultimately, the fraction of photo-generated charges resulting in chemical reactions with other molecules is low, frequently in the region of 1 to $2 \%$ (Stafford et al. 1997).

Reaction with molecules of interest can occur either directly or indirectly. In a direct reaction, an organic molecule on the $\mathrm{TiO}_{2}$ surface is reduced by $\mathrm{e}_{\mathrm{CB}}^{-}$, or is oxidized by having an electron stripped by $\mathrm{h}_{\mathrm{VB}}^{+}$. In an indirect reaction, the direct reaction is with water molecules, dissolved oxygen, or other intermediates. Importantly, direct and indirect reactions both produce 
131 radicals, since each reaction involves only one electron and therefore upsets the even number of 132 valence electrons found in most molecules, leaving an electron unpaired. A direct reaction with 133 an organic molecule therefore produces an unstable organic radical, which will undergo further reactions in solution that are likely to result in one or more bond cleavages. Indirect reactions are important because the initial products are radicals that can then attack organic molecules in aqueous solution. Radicals participate in a variety of reactions with organic and inorganic molecules in solution, spawning a wide set of radical species (Hoffmann et al. 1995).

Thus, UV irradiation of $\mathrm{TiO}_{2}$ in water quickly results in a suite of radicals with complex chemistry (see Figure 2). Two indirect reactions will be singled out as having particular importance. First, the hole can oxidize water (or hydroxide ions) to form the hydroxyl radical, $\mathrm{OH}^{*}$. This is a very strong and indiscriminant radical with rapid kinetics for reaction with almost any molecule it encounters. There has been a long debate in photocatalysis as to whether the hole is a strong enough oxidant to generate a true free hydroxyl radical, or only a bound species. A free hydroxyl radical can diffuse through the surrounding water to attack various dissolved molecules, but because of its reactivity it does not travel more than a few nanometers from the particle surface. On the other hand, a bound hydroxyl radical is simply the chemical speciation of a trapped hole. It has been demonstrated that an irradiated $\mathrm{TiO}_{2}$ film can degrade an organic film across an air gap (Tatsuma et al. 1999; 2001), indicating mobility of some active species. Hydroxyl radicals in particular have been detected in the gas phase over irradiated $\mathrm{TiO}_{2}$ powder, indicating that a free $\mathrm{OH}^{\bullet}$ is generated (Murakami et al. 2007). Second, the electron can be taken by molecular oxygen to form the superoxide radical $\mathrm{O}_{2}{ }^{-}$. This radical product engages in a series of reactions with water, oxygen, and additional $\mathrm{e}_{\mathrm{CB}}^{-}$, generating a suite of activated oxygen species including $\mathrm{HO}_{2}{ }^{\circ}, \mathrm{HO}_{2}{ }^{-}, \mathrm{H}_{2} \mathrm{O}_{2}$, and $\mathrm{OH}^{\circ}$. All of these are reactive and can oxidize organic 
molecules. Any of the uncharged species could be involved in the above mentioned reaction across an air gap; while in water, all of the species can travel in solution to interact with organics.

It is important to note that a reaction with $\mathrm{e}_{\mathrm{CB}}^{-}$or $\mathrm{h}_{\mathrm{VB}}^{+}$is consequential not just for the radicals it produces, but because it deprives the opposite charge in $\mathrm{TiO}_{2}$ of a partner for recombination, ensuring that both charges will ultimately react. In particular, it is thought that the reaction of $\mathrm{O}_{2}$ with $\mathrm{e}_{\mathrm{CB}}^{-}$is important mainly because it is relatively rapid and allows $\mathrm{h}_{\mathrm{VB}}^{+}$time to perform an oxidation reaction. Molecular oxygen therefore plays the role of an electron scavenger, providing time for $\mathrm{h}_{\mathrm{VB}}^{+}$to react.

\section{Light intensity and attenuation in aquatic environments - a critical consideration}

An understanding of the interactive effects of UV light and $\mathrm{TiO}_{2} \mathrm{NP}$ on aquatic organisms requires an appreciation and comprehension of the light fields experienced by the organisms in the natural environment. Latitude, season, time of day, and atmospheric conditions all act to modulate the amount of light energy that reaches the surface of lakes, rivers and marine waters. After transmission across the surface, light is attenuated with depth through interaction with water molecules and the optically active constituents of the water column. While the literature of in-water optics is extensive, a basic explanation is provided here. For more information, the reader is directed to the references cited, particularly Kirk (1994) and Mobley (1994).

Natural waters contain a variety of organic and inorganic substances which absorb and scatter light differentially by wavelength (Kirk 1994), including colored dissolved organic matter (CDOM), phytoplankton, and non-algal particles (NAP) such as mineral and organic sediments, bacteria, and zooplankton (Belzile et al. 2004). The combination of these substances, therefore, determines the overall intensity (total photon or energy flux) and spectral distribution (the relative amount of photons or energy at a given wavelength) of the local light field. 
Attenuation, the total decrease in light with distance through the water column, is the sum

178

of absorption and scattering (Dierssen \& Randolph 2013; Kirk 1994; Mobley 1994). Absorption

removes photons from the light field, while scattering redirects them (Mobley 1994). Scattering

increases the chances that a photon will be absorbed by increasing its path length. Some scattered photons will be transmitted back up and across the surface, leaving the water column entirely.

This includes those reflected off of the bottom in shallow environments. These upwardly scattered photons represent only a tiny fraction of the light initially entering the water column, with the vast majority being eventually absorbed (Dierssen \& Randolph 2013).

Pure water absorption is significant in the UV, weak in the blue, and increases exponentially with wavelength (Lu 2006; Morel et al. 2007; Pope \& Fry 1997; Smith \& Baker 1981). As a result, clear oceanic waters without significant photoactive constituents (like CDOM or phytoplankton) transmit blue and green light to depth, while red wavelengths are depleted near the surface (Kirk 1994; Morel 1988). Phytoplankton will absorb blue and red wavelengths while transmitting green, according to the absorption spectra of chlorophyll $a$ (Kirk 1994) and other pigments. Different groups of phytoplankton contain a variety of photosynthetic pigments, so the exact absorption spectrum will depend on the identity and concentration of the 193 phytoplankton (Morel 1988; Dierssen et al. 2006; Roy et al. 2011). Produced from the decay of 194 plant matter and abundant in terrestrial and coastal waters, CDOM is operationally defined as 195 those substances which pass through a $0.2 \mu \mathrm{m}$ filter (Dierssen \& Randolph 2013) and absorbs 196 strongly in the UV and blue wavelengths, but absorption decreases exponentially towards the red 197 (Belzile et al. 2002; Kirk 1994; Twardoski et al. 2004). The absorption of organic and mineral 198 particles is typically greatest at short wavelengths, i.e. the UV and blue, but the exact shape of 199 the absorption spectrum is determined by the properties of the particles themselves (Morel \& 
Ahn 1990; Belzile et al. 2004; Kirk 1994), such as mineral content and organic coating. These particles are the optically active component most responsible for scattering (Aurin \& Dierssen 2012; Babin et al. 2003a; Kirk 1994; Mobley 1994; Vincent et al. 2001).

Aqueous environments are a complex combination of water, CDOM, particles, and plankton. As a result, the local light field can vary dramatically with time, weather, region, and depth, particularly in coastal ocean areas and in-land water bodies (Babin et al. 2003b; Belzile et al. 2004; Etheridge \& Roesler 2004; Kirk 1994; McPherson et al. 2011; Vincent et al. 2001). A common, straightforward metric of light intensity is Photosynthetically Available Radiation (PAR), the integrated photon flux from 400 - 700 nm (Dierssen \& Randolph 2013; Kirk 1994). However, PAR provides only a relative indicator of UV levels. For the study of photocatalysis in natural waters, it is imperative that the intensity and spectral distribution of the light at relevant wavelengths be understood. While these can be measured in situ with spectrally resolved irradiance sensors, it is possible to accurately model light through the use of software such as Hydrolight (Sequioa Scientific) which can account for a variety of latitudes, times, atmospheric conditions, and water column compositions. For example, optical simulations of Long Island Sound (LIS) irradiances just below the surface are more than two times higher in the summer than in the winter (Fig. 3; integrated PAR values: $16.9-40.4 \mathrm{~mW} / \mathrm{cm}^{2}$ ). Additionally, LIS irradiance changes drastically with depth, dropping to only $2.04 \mathrm{~mW} / \mathrm{cm}^{2}$ at $5 \mathrm{~m}$ depth (Fig. 4;). Comparing the irradiance in LIS $\left(41^{\circ} \mathrm{N}\right)$ to three other latitudes at the same depth and season shows that latitude has a significant impact (see Fig. 5). A latitude of $1^{\circ} \mathrm{N}$ has an irradiance of $43.3 \mathrm{~mW} / \mathrm{cm}^{2}$ just below the surface, which is twice the irradiance at $48^{\circ} \mathrm{N}$. The parameters used in these simulations are described in the figure legends.

In addition to its spectral and intensity components, the directionality of underwater light 
223 must be considered for accurate characterization. Mobley (1994) provides a thorough

224 characterization, elements of which are discussed here. The downward planar irradiance $\left(E_{d}\right)$ is

225 the downward directed light from the entirety of the upper hemisphere at a given depth (Dierssen

226 \& Randolph 2013; Mobley 1994). That is, the photons directed downwards within the water

227 column through a horizontal plane. Light decreases exponentially according to the downward 228 diffuse attenuation coefficient $\left(\mathrm{K}_{\mathrm{d}}\right)$, as described by Beer's Law (Kirk 1994; Dierssen \&

229 Randolph 2013; Russell \& Dierssen 2015):

$$
E_{d}(z)=E_{d}\left(0^{-}\right) e^{-K_{d} z}
$$

230 where $\mathrm{E}_{\mathrm{d}}(\mathrm{z})$ is downward irradiance at depth $\mathrm{z}$, and $\mathrm{E}_{\mathrm{d}}\left(0^{-}\right)$is irradiance just below the surface. 231 Both $E_{d}\left(0^{-}\right)$and $K_{d}$ are functions of the wavelength $(\lambda)$, and therefore $E_{d}(z)$ has different values 232 for every wavelength within the region considered (Fig. 3). This relationship is the basis for the 233 differential penetration to depth of regions of the light spectrum.

In particular, UVA/B is rapidly attenuated by water, CDOM, and sediments (Babin et al. 2003b; Belzile et al. 2002; Vincent et al. 2001), with values of UVA often $<1 \mathrm{~W} / \mathrm{m}^{2} / \mathrm{nm}$ at depths of $>1 \mathrm{~m}$ (Wozniak \& Dera 2007). In many coastal environments, a downwardtransmission maximum occurs between 500 and $550 \mathrm{~nm}$, decreasing rapidly above and below these wavelengths (Kirk 1994). For example, just below the surface of the ocean the downward irradiance, $\mathrm{E}_{\mathrm{d}}\left(0^{-}\right)$, at $400 \mathrm{~nm}$ can be 3 to 5 times higher than the downward irradiance at $320 \mathrm{~nm}$ (UVA/UVB delineation; EUR 22217 EN 2006). Incident power of sunlight drops off around 450 $\mathrm{nm}$ in air as well, however, the change with depth is more drastic in water compared to air. Nonetheless, UV radiation does penetrate to depths that are ecologically significant (Vincent et al. 2001), and many aquatic species have mechanisms for photoprotection (Häder et al. 2007). The optical attributes of natural waters have not been fully considered in most previous studies 
with photoactive NP, and research that has reported phototoxicity to aquatic organisms using 'terrestrial' irradiance levels should be interpreted with caution (e.g., Matsuo et al. 2001; HundRinke \& Simon 2006).

\section{Interactions with the biological and physicochemical elements of aquatic environments}

The environmental fate (transport \& retention) of NP is influenced by properties of the 250 surrounding media, including $\mathrm{pH}$, ionic strength, and the concentration of organic material 251 (Guzman et al. 2006; Domingos et al. 2009; French et al. 2009; Petosa et al. 2010).

252 Physicochemical interactions between NP and aqueous constituents have been well described, 253 and have been demonstrated to affect agglomeration potential (Sillanpää et al. 2011; Shih et al. 254 2012; Doyle et al. 2014) and formation of homo- and hetero-aggregations (Brant et al. 2005; 255 Navarro et al. 2008; Xie et al. 2008; Domingos et al. 2009; Johnson et al. 2009; Sharma 2009). 256 Organic constituents of aqueous environments can also affect the photoreactivity of $\mathrm{TiO}_{2} \mathrm{NP}$. 257 For example, dissolved organic matter (DOM) can accelerate degradation of surfactant coatings 258 of some NP, increasing their reactivity (e.g., glycerine \& aluminum coating on UV-Titan, a type 259 of $\mathrm{TiO}_{2} \mathrm{NP}$; Aiken et al. 2011). Therefore, as nanomaterials 'age' in the environment their 260 potential for risk can increase. On the other hand, DOM and natural organic matter (NOM) can 261 influence the bioavailability of nanomaterials through NP association with other particles; the 262 degree by which bioavailability is affected, however, depends on the organism and route of 263 exposure (Aiken et al. 2011; Yang 2009). There is also evidence that NOM, comprised mainly of 264 humic and fulvic substances, is a photosensitizer and ROS quencher (Golanoski et al. 2012; 265 Nurmi \& Tratnyek 2002), able to reduce the photoactivity of NP. Natural organic matter has 266 been shown to decrease the toxicity of $\mathrm{TiO}_{2}$ NP to Daphnia magna under natural light conditions 267 (4-hr SSR) (Li et al. 2016). Similarly, Yang et al. (2013) found that humic acids (HA) coating 
$\mathrm{TiO}_{2}$ NP increased stability and reduced NP exposure to zebrafish. However, when the solutions were exposed to simulated sunlight, the photoactive NP degraded the HA coating, and oxidative 270 deoxyribonucleic acid (DNA) damage and mortality increased in the zebrafish. Lastly, it has 271 been found that lake water with high dissolved organic carbon (DOC) concentrations make NP 272 more stable and therefore more toxic to bacteria (Farkas et al. 2015). These findings highlight the 273 complexity of NP interactions with aqueous constituents and the importance of considering 274 environmental factors when assessing risk of nanomaterials. In addition to chemical properties of 275 water, there are also physical and biological processes that can affect NP interactions.

Physical and biological processes of aquatic systems operate to aggregate smaller 277 particles into larger masses $(100$ s of $\mu \mathrm{m})$ referred to as marine, lake, or river snow (aka, 278 macroaggregates, flocs; Alldredge \& Silver 1998; Jackson 1990; see fig. in Azam \& Malfatti 279 2007). In the marine environment, large proportions (> 70\%) of natural particulates are 280 incorporated in marine snow at certain times of the year (Alldredge et al. 1993; Crocker \& 281 Passow 1995). In the laboratory, $\mathrm{TiO}_{2} \mathrm{NP}$ can be incorporated into marine snow at efficiencies 282 that exceed ca. $70 \%$ after $24 \mathrm{hrs}$. If such incorporation occurs in the natural environment it would 283 expose the diverse community of microorganisms that reside in marine snow (Azam \& Long 284 2001; Simon et al. 2002; Kiørboe et al. 2003; Lyons et al. 2007) to a high concentration of NP 285 relative to the water. Although aggregates tend to sink out of the photic zone faster than 286 individual particles (Stokes Law; Hill 1998; Waite et al. 2000), tidal forces and storm events can 287 re-suspend settled aggregates and re-expose them to light (e.g., Lyons 2008). Within an 288 aggregate, some NP could be shielded from light and be less reactive, or brought into contact 289 with microorganisms producing more deleterious effects. Given the importance of organic 290 aggregates and their constituent microorganisms to biogeochemical processes and ecology of 
292 2002), understanding the effects of NP and light on the microbial communities that inhabit 293 aggregates is a fertile area for future research.

\section{Nanoparticulate and photocatalytic effects of $\mathrm{TiO}_{2} \mathrm{NP}$ on aquatic organisms}

Similar to other nanomaterials, $\mathrm{TiO}_{2} \mathrm{NP}$ have the potential to be toxic to cells and tissues, likely attributed to their infinitesimal size, high surface area and reactivity (Johnston et al. 2009; Blaise et al. 2008; Schultz et al. 2014; Scown et al. 2010). The infinitesimal size of nanomaterials facilitates their movement across cellular membranes and into organelles where they can generate ROS that can damage DNA and proteins (Simic \& Jovanovic 1986; Deng \& Fridovich 1989), and interfere with the structural integrity of the cell membrane (Moore 2006). Some metal-oxide NP also are photocatalysts. When activated by sufficient light energy, they form radicals that can produce oxidative stress and damage cells in contact with the NP (see section 2 above; Fujishima et al. 2000; Mills \& Lee 2002; Sharma 2009). Although the absorption-band cut-off of various forms of $\mathrm{TiO}_{2}$ are different, most absorb strongly in the UVA (320-400 nm) and UVB (290-320 nm) range (ca. 80-90\% absorption; Li \& Ishigaki 2003). Thus, NP interacting with UV light in the natural environment can have deleterious effects on organisms that are in addition to those effects caused by NP in the absence of light.

Studies on several species of fish and invertebrates demonstrate that $\mathrm{TiO}_{2} \mathrm{NP}$ can be ingested or otherwise taken up by aquatic organisms (e.g., Griffitt et al. 2008; Galloway et al. 2010), including by several species of bivalve molluscs (e.g., Canesi et al. 2010; Couleau et al. 2012; Doyle et al. 2015). Bioaccumulation of $\mathrm{TiO}_{2} \mathrm{NP}$ has also been reported in viscera and gills of carp, intestine and gills of goldfish and tissues of rainbow trout (Sun et al. 2007; Zhang et al. 2007; Mehmet et al. 2013; Federici et al. 2007; see also review by Nam et al. 2014). The level of 
314 bioaccumulation and the amount of time required for elimination of nanoscale titania from 315 tissues, however, has been little studied. For some types of $\mathrm{TiO}_{2} \mathrm{NP}$, oysters, Crassostrea

Adverse effects in some species of bivalves have also been reported including reduced phagocytosis capability of hemocytes after 2 to 24-hour exposure times (Chalew et al. 2012; Canesi et al. 2010; Ciacci et al. 2012; Couleau et al. 2012), and further impacts on the immune function including decreased hemocyte viability, reduced phagocytosis capability and an increase in ROS production after longer, 4 to 9-day exposure times (Barmo et al. 2013; Canesi et al. 2014; Wang et al. 2014). For a more detailed review on the impacts of NP on bivalves, we refer readers to the review by Canesi et al. (2012). Adhesion of $\mathrm{TiO}_{2} \mathrm{NP}$ to the exoskeleton of planktonic organisms can also produce physical effects such as loss of mobility (Baun et al. 2008; Miller et al. 2012), and NP incorporation into phytoplankton cells can limit growth (Li et al. 2015). In contrast, some studies have reported little or no toxic effects from $\mathrm{TiO}_{2} \mathrm{NP}$ on several aquatic species, including D. magna (48-hr), Daphnia pulex (48-hr), Danio rerio (48-hr), and Oncorhynchus mykiss (96-hr), (e.g., Warheit et al. 2007, 10-100 mg/l; Griffitt et al. 2008, up to $10 \mathrm{mg} / \mathrm{l}$ ), despite using very high concentrations of $\mathrm{TiO}_{2} \mathrm{NP}$. The reasons behind the minimal toxicity in these cases is uncertain, but are possibly due to variations in experimental design (e.g., sonication techniques). Although the above studies provide a good foundation, many of 

338 and high NP concentrations (> $10 \mathrm{mg} / \mathrm{L}$ ), and thus are difficult to extrapolate to natural 339 ecosystems where animals likely experience chronic exposures of lower NP concentrations.

Increasing numbers of studies have been designed to examine photocatalytic effects of $\mathrm{TiO}_{2}$ on aquatic organisms, in particular the interactive effects of $\mathrm{UV}$ radiation and $\mathrm{TiO}_{2} \mathrm{NP}$ on freshwater species. UV was most commonly delivered from benchtop lamps containing outputs in the 340-420 $\mathrm{nm}$ range. Under such exposure conditions, nanoscale $\mathrm{TiO}_{2}$ (anatase) and UVA can produce low cell viability in goldfish skin cells after only 2 hours (340-420 nm; Reeves et al. 2008), and suppress growth in both freshwater and marine phytoplankton (Lee \& An 2013, Metzler et al. 2011, Miller et al. 2012). Similarly, Vevers and Jha (2008) found that the genotoxic effects of $\mathrm{TiO}_{2}$ was enhanced when fish (O. mykiss) cells were exposed to NP (e.g., 5$50 \mu \mathrm{g} / \mathrm{ml})$ and UV light (340-420 nm; 0.08-0.17 mW/m²) in vitro. P25 NP were significantly more toxic to D. magna when the animals were exposed to UVA light (340-420 nm, 0.56 $\mathrm{mW} / \mathrm{cm}^{2}$; Amiano et al. 2012). In contrast, neither anatase nor rutile forms of $\mathrm{TiO}_{2} \mathrm{NP}$ were toxic to Daphnia similis when exposed to UVA and visible light for 2 days (Marcone et al. 2012). In a number of studies, a Simulated Solar Radiation (SSR) apparatus was used which included a temperature-controlled water bath and lamps that mimic solar radiation in the range of $280-800 \mathrm{~nm}$. The output of SSR can be adjusted using neutral density filters to lower or eliminate UV. Those studies that use SSR to achieve a 4-hour dose of UV during each experimental day have all shown negative impact of P25 NP, resulting in mortality in D. magna, Japanese medaka fish larvae, and freshwater benthic invertebrates (Ma et al. 2012, Li et al. 2014a \& b), and ROS production and oxidative stress in D. rerio embryos (Faria et al. 2014).

them neglect environmentally-relevant interactions, including acute exposure times $(<48$ hours $)$ 
A few studies have used natural light to examine the interaction between NP and environmentally-relevant irradiances. One marine study performed on hepatopancreas tissue of oysters (C. virginica) used controlled levels of natural sunlight to 'activate' NP solutions prior to adding them to the tissue samples, and found a decrease in lysosomal stability (Johnson et al. 2015). Unfortunately, the researchers only measured PAR (400-700 nm) so the amount of UV and the wavelengths to which the NP were exposed is unknown. Additionally, the kinetics of photoactive NP are rapid, with reactions stopping once NP are no longer exposed to light. Thus, the method of pre-activating NP prior to experiments in order to achieve photocatalytic effects does not align with known chemical reaction times and researchers need to demonstrate the lasting effects of pre-exposure using proxy assays. Mansfield et al. (2015) also used natural outdoor sunlight and filters to achieve 10, 50 and 100\% ambient light levels and found significant mortality of D. magna, however, this study used high NP concentrations (20 and 200 ppm).

Although valuable data have been obtained on the interactive effects of UV light and nanoscale titania, it is difficult to compare and contrast results of previous studies because of the varied methodologies employed. For example, the light levels used in the aforementioned experiments ranged from UVA only $(340-420 \mathrm{~nm})$ to full spectrum $(280-800 \mathrm{~nm})$, and UV exposure durations ranged from minutes to days (see Table 1). Another inconsistency is using high UV intensities that correspond to irradiances above the water surface instead of a light field that matches the organism's environment (see section 3 above). Additionally, none of the studies measured how much UV was absorbed by the experimental containers in which the animals were held, which included glass beakers, petri dishes and containers with and without lids. Lastly, there is a lack of consideration of the constituents of the aqueous media that could affect UV 
intensity. Whether results of these studies can be applied to the natural environment, therefore, is uncertain.

384 Certainly, as a photoreactive material $\mathrm{TiO}_{2} \mathrm{NP}$ have the potential to produce deleterious 385 effects on organisms at all levels of biological organization when activated by the correct 386 wavelengths of UV at sufficient intensities. A main consideration, however, is whether the 387 selected wavelengths and their intensities used in laboratory-based experiments are relevant to 388 organisms that live within the natural environment. For example, UV penetration in water 389 changes drastically with different water properties (e.g., oceanic vs. coastal water bodies, 390 chlorophyll $a, \mathrm{CDOM}$ and turbidity), and latitude and season both act to alter the light spectrum 391 in the natural environment (Kirk 1994; Mobley 1994). It has also been shown that $10 \%$ of the 392 surface irradiance penetrates to a depth of 10 meters in some coastal waters, and UVB is still 393 detectable at 1-meter depth in some locations (Booth et al. 1997). Farkas et al. (2015) found that 394 ecologically significant UV-PAR levels (below surface and $1 \mathrm{~m}$ depth) did not increase toxicity 395 of $\mathrm{TiO}_{2}$ NP to freshwater bacteria compared to treatments without UV-PAR exposure. Another 396 consideration is the interactions between NP and dissolved, colloidal, and particulate material of 397 the system. As highlighted in section 4 above, it has been shown that the interactions of NP with 398 water constituents such as DOM and DOC can complicate the behavior of NP in water, including 399 the homo- and hetero-aggregation of NP. It is crucial that researchers understand how NP 400 interact with the surrounding aqueous media, and how UV intensity can change with different $401 \quad$ water properties.

\section{6. Recommendations for future studies}

There have been a limited number of studies investigating the photocatalytic effects of $\mathrm{TiO}_{2} \mathrm{NP}$ on aquatic organisms. The few studies that have been conducted all differ in NP 
concentration, light intensity, and duration, and highlight a lack of consensus in the field on how to perform these types of experiments. For future studies, it is paramount to carefully define the light level used in experimental exposures. Additionally, radicals produced by UV activation are short-lived, so effects on oxidative stress cannot be accurately measured without constant UV dosing. Researchers also need to be careful when using SSR, because while it is a good starting point, its output is not intended for aqueous environments. Filters can be used to adjust intensity and wavelength of exposure, but these simulated light levels must be appropriate for the depth, latitude, season, and water column parameters that the organism being studied would experience. Also, given UV-damage repair mechanisms, such as those well-studied in phytoplankton (see Sinha \& Häder 2002), the question remains - is a high dose over 4 hours comparable to a lower dose over a longer period? Therefore, we suggest that the duration of UV exposure be relevant to natural light fields in order to maintain NP reactivity (e.g., 15 hour light exposure : 9 hour dark exposure for summer light levels). Additionally, UV intensity can change in response to physical and biological characteristics of the water (i.e., chlorophyll $a$, turbidity, CDOM, DOC). Specifically, for marine systems, it is important to consider the incorporation of NP into larger aggregations, and how certain physicochemical properties (i.e., mixing, DOC) can affect NP suspension in experimental matrices, both of which have the potential to alter the photoreactivity and exposure of nanomaterials. Therefore, it is necessary to use an optical model (i.e., Hydrolight) that incorporates water characteristics in order to select an appropriate light spectrum. Prior to experimentation, researchers should characterize the natural system in which the organisms they are studying live. The output from experimental solar lamps should then be matched to the modeled light spectrum that corresponds to the natural system using a spectroradiometer. It is also critical to use a light source that includes both UVA and UVB 
wavelengths, as they have been shown to be ecologically significant, even in some coastal systems (Booth et al. 1997). Additionally, studies that used only UV light should be re-evaluated 430 because visible light is required for photolyases which repair DNA caused by UV damage 431 (Rupert et al. 1958). Visible light also is necessary in some cases to maintain the normal 432 behavioral and physiological functions of some animals (e.g., phytoplankton and zooplankton). 433 Finally, experiments that are being performed in a closed system should include reported 434 measurements of UV-vis absorption by experimental bottles and containers with lids.

435 Although only a relatively small number of aquatic organisms have been investigated, 436 there is increased interest in assessing the impacts on aquatic environments. Therefore, the 437 recommendations we outline here are important for future studies to more accurately predict the 438 effects of $\mathrm{TiO}_{2} \mathrm{NP}$ on aquatic organisms. We suggest that researchers in this field move away 439 from a toxicological perspective (i.e., eliciting mortality with extreme doses) and towards an 440 ecotoxicological approach where animal exposures are carried out under environmentally441 relevant conditions. The behavior of NP in aqueous media suggests they have the ability to 442 impact a wide range of organisms, from the smallest particle-attached bacterium to a filter443 feeding bivalve. We also must consider that certain organisms could be more vulnerable to 444 photoreactive NP depending on their natural history, e.g., translucent filter feeders that are 445 frequently exposed to sunlight. It is necessary to carry out experiments considering natural 446 conditions to better define the risk associated with photoreactive nanomaterial exposures.

\section{Acknowledgements}

448 This research was supported by grants from National Science Foundation's Environmental 449 Nanotechnology program (CBET-1336358) and U.S. Department of Agriculture/NIFA (\# 2016450 67017-24427) to J. Evan Ward. 
2

3

\section{Declarations of interest}

7452 The author's affiliation is as shown on the cover page. The authors have sole responsibility for 8

9453 the writing and content of the paper. 


\section{References}

Adams LK, Lyon DY, Alvarez PJJ. 2006. Comparative eco-toxicity of nanoscale TiO2, SiO2, and $\mathrm{ZnO}$ water suspensions. Wat. Res. 40(19): 3527-3532.

Aiken GR, Hsu-Kim H, Ryan JN. 2011. Influence of dissolved organic matter on the environmental fate of metals, nanoparticles, and colloids. Environ. Sci. and Technol. 45: 31963201.

Alldredge AL. 2000. Interstitial dissolved organic carbon (DOC) concentrations within sinking marine aggregates and their potential contribution to carbon flux. Limnol. Oceanogr. 45(6): 1245-1253.

Alldredge AL, Jackson GA. 1995. Preface: Aggregation in Marine Systems. Deep-Sea Res., II, Top. Stud. In Oceanogr. 42: 1-7.

Alldredge AL, Passow U, Logan BE. 1993. The abundance and significance of a class of large, transparent organic particles in the ocean. Deep-Sea Res. 40: 1131-1140.

Alldredge AL, Silver MW. 1998. Characteristics, dynamics and significance of marine snow. Prog. In Oceanography 20(1): 41-82.

Alrousan DMA, Dunlop PSM, McMurray TA, Byrne JA. 2009. Photocatalytic inactivation of E. coli in surface water using immobilised nanoparticle $\mathrm{TiO}_{2}$ films. Water Res. 43: 47-54.

Amiano I, Olabarrieta J, Vitorica J, Zorita S. 2012. Acute toxicity of nanosized TiO2 to Daphnia magna under UVA irradiation. Environ. Toxicol. and Chem. 31(11): 2564-2566.

Asahi R, Morikawa T, Ohwaki T, Aoki K, Taga Y. 2001. Visible-Light Photocatalysis in Nitrogen-Doped Titanium Oxides. Science. 293: 269-271.

Aurin DA, Dierssen HM. 2012. Advantages and limitations of ocean color remote sensing in CDOM-dominated, mineral-rich coastal and estuarine waters. Remote Sensing of Environ. 125: 181-197.

Azam F, Long RA. 2001. Oceanography: Sea snow microcosms. Nature. 414: 495-498.

Azam F, Malfatti F. 2007. Microbial structuring of marine ecosystems. Nat. Rev. Micro. 5: 782791.

Babin M, Morel A, Fournier-Sicre V, Fell F, Stramski D. 2003a. Light scattering properties of marine particles in coastal and open ocean waters as related to the particle mass concentration. Limnol. Oceanogr. 48(2): 843-859.

Babin M, Stramski D, Ferrari GM, Claustre H, Bricaud A, Obolensky G, Hoepffner N. 2003 b. Variations in the light absorption coefficients of phytoplankton, nonalgal particles, and dissolved organic matter in coastal waters around Europe. J. of Geophys. Res. 108: 1-20. 
Barmo C, Ciacci C, Canonico B, Fabbri R, Cortese K, Balbi T, Marcomini A, Pojana G, Gallo G, Canesi L. 2013. In vivo effects of $\mathrm{n}-\mathrm{TiO} 2$ on digestive gland and immune function of the marine bivalve Mytilus galloprovincialis. Aquatic Toxicol. 132-133: 9-18.

Baun A, Hartmann NB, Grieger K, Kusk KO. 2008. Ecotoxicity of engineered nanoparticles to aquatic invertebrates: a brief review and recommendations for future toxicity testing. Ecotoxicol. 17: 387-395.

Belzile C, Vincent WF, Kumagai M. 2002. Contribution of absorption and scattering to the attenuation of UV and photosynthetically active radiation in Lake Biwa. Limnol. Oceanogr. 47: 95-107.

Belzile C, Vincent WF, Howard-Williams C, Hawes I, James MR, Kumagai M, Roesler CS. 2004. Relationships between spectral optical properties and optically active substances in a clear oligotrophic lake. Water Resources Res. 40: 1-13.

Benabbou AK, Derriche Z, Felix C, Lejeune P, Guillard C. 2007. Photocatalytic inactivation of Escherischia coli: Effect of concentration of $\mathrm{TiO}_{2}$ and microorganism, nature, and intensity of UV irradiation. Appl. Caltal. B: Env. 76: 257-263.

Blaise C, Gagné F, Férard JF, Eullaffroy P. 2008. Ecotoxicology of selected nano-materials to aquatic organisms. Environ. Toxicol. 23(5): 591-598.

Booth CR, Morrow JH, Coohill TP, Cullen JJ, Frederick JE, Häder D-P, Holm-Hansen O, Jeffrey WH, Mitchell DL, Neale PJ, et al. 1997. Impacts of solar UVR on aquatic microorganisms. Photochem. and Photobiol. 65(2): 252-269.

Brant J, Lecoanet H, Wiesner MR. 2005. Aggregation and deposition characteristics of fullerene nanoparticles in aqueous systems. J. of Nanopart. Res. 7(4): 545-553.

Canesi L, Ciacci C, Vallotto D, Gallo G, Marcomini A, Pojana G. 2010. In vitro effects of suspensions of selected nanoparticles (C60, fullerene, $\mathrm{TiO} 2, \mathrm{SiO} 2)$ on Mytilus hemocytes. Aquatic Toxicol. 96(2): 151-158.

Canesi L, Ciacci C, Fabbri R, Marcomini A, Pojana G, Gallo G. 2012. Bivalve molluscs as a unique target group for nanoparticle toxicity. Mar. Environ. Res. 76: 16-21.

Canesi L, Frenzilli G, Balbi T, Bernardeschi M, Ciacci C, Corsolini S, Della Torre C, Fabbri R, Faleri C, Focardi S, et al. 2014. Interactive effects of n-TiO2 and 2,3,7,8-TCDD on the marine bivalve Mytilus galloprovincialis. Aquatic Toxicol. 153: 53-65.

Chalew TE, Galloway JF, Graczyk TK. 2012. Pilot study on effects of nanoparticle exposure on Crassostrea virginica hemocyte phagocytosis. Mar. Poll. Bull. 64: 2251-2253.

Cho M, Chung H, Choi W, Yoon J. 2004. Linear correlation between inactivation of E. coli and $\mathrm{OH}$ radical concentration in TiO2 photocatalytic disinfection. Wat. Res. 38: 1069-1077.

Chorianopoulos NG, Tsoukleris DS, Panagou EZ, Falaras P, Nychas G-JE. 2011. Use of titanium dioxide $\left(\mathrm{TiO}_{2}\right)$ photocatalysts as alternative means for Listeria monocytogenes biofilm disinfection in food processing. Food Micro. 28: 164-170. 
Ciacci C, Canonico B, Bilaniĉovă D, Fabbri R, Cortese K, Gallo G, Marcomini A, Pojana G, Canesi L. 2012. Immunomodulation by Different Types of N-Oxides in the Hemocytes of the Marine Bivalve Mytilus galloprovincialis. PLoS ONE. 7(5): e36937.

Clément L, Hurel C, Marmier N. 2013. Toxicity of TiO2 nanoparticles on cladocerans, algae, rotifers, and plants - effects of size and crystalline structure. Chemosphere. 90: 1083-1090.

Clemente Z, Castro VL, Jonsson CM, Fraceto LF. 2014. Minimal levels of ultraviolet light enhance the toxicity of $\mathrm{TiO} 2$ nanoparticles to two representative organisms of aquatic systems. J. Nanopart. Res. 16(2559): 1-16.

Couleau N, Techer D, Pagnout C, Jomini S, Foucaud L, Laval-Gilly P, Falla J, Bennasroune A. 2012. Hemocyte responses of Dreissena polymorpha following a short-term in vivo exposure to titanium dioxide nanoparticles: preliminary investigations. Sci. of the Tot. Environ. 438: 490497.

Crocker KM, Passow U. 1995. Differential aggregation of diatoms. Mar. Ecol. Prog. Ser. 117: 249-257.

Deng RY, Fridovich I. 1989. Formation of endonuclease III-sensitive sites as a consequence of oxygen radical attack on DNA. Free Radical Biol. Med. 6: 123-129.

Dhandapani P, Maruthamuthu S, Rajagopal G. 2012. Bio-mediated synthesis of $\mathrm{TiO}_{2}$ nanoparticles and its photocatalytic effect on aquatic biofilm. J. Photochem. Photobiol. B: Biol. 110: 43-49.

Dierssen HM, Kudela RM, Ryan JP, Zimmerman RC. 2006. Red and black tides: Quantitative analysis of water-leaving radiance and perceived color of phytoplankton, colored dissolved organic matter, and suspended sediments. Limnol. Oceanogr. 51(6): 2646-2659.

Dierssen HM Randolph K. 2013. Remote sensing of ocean color. Earth Sys. Monitor. 439-472.

Domingos RF, Tufenkji N, Wilkinson KI. 2009. Aggregation of titanium dioxide nanoparticles: Role of a fulvic acid. Environ. Sci. Technol. 43(5): 1282-1286.

Doyle JJ, Palumbo V, Huey BD, Ward JE. 2014. Behavior of titanium dioxide nanoparticles in three aqueous media samples: agglomeration and implications for benthic deposition. Water Air Soil. Pollut. 225(2106): 1-13.

Doyle JJ, Ward JE, Mason R. 2015. An examination of the ingestion, bioaccumulation, and depuration of titanium dioxide nanoparticles by the blue mussel (Mytilus edulis) and the eastern oyster (Crassostrea virginica). Mar. Environ. Res. 110: 45-52.

Doyle JJ, Ward JE, Mason R. 2016. Exposure of bivalve shellfish to titania nanoparticles under an environmental-spill scenario: encounter, ingestion and egestion. J. of the Marn. Biol. Assoc. of the UK. 96(1): 137-149.

Etheridge SM, Roesler CS. 2004. Temporal variations in phytoplankton, particulates, and colored dissolved organic material based on optical properties during a Long Island brown tide compared to an adjacent embayment. Harmful Algae. 3: 331-342. 
EUR 22217 EN. 2006. UV penetration in the water column. DG Joint Research Centre, Institute for Environment and Sustainability; Scientific and Technical Research series; Office for Official Publications of the European Communities. Luxembourg, 2006.

Faria M, Navas JM, Soares AMVM, Barata C. 2014. Oxidative stress effects of titanium dioxide nanoparticle aggregates in zebrafish embryos. Sci. of the Tot. Environ. 470-471: 379-389.

Farkas J, Peter H, Ciesielski TM, Thomas KV, Sommaruga R, Salvenmoser W, Weyhenmeyer GA, Tranvik LJ, Jenssen BM. 2015. Impact of $\mathrm{TiO} 2$ nanoparticles on freshwater bacteria from three Swedish lakes. Sci. of the Total. Environ.

http://dx.doi.org/10.1016/j.scitotenv.2015.03.043.

Federici G, Shaw BJ, Handy RD. 2007. Toxicity of titanium dioxide nanoparticles to rainbow trout (Oncorhynchus mykiss): gill injury, oxidative stress and other physiological effects. Aquat. Toxicol. 84: 415-430.

French RA, Jacobson AR, Kim B, Isley SL, Penn RL, Baveye PC. 2009. Influence of ionic strength, $\mathrm{pH}$, and cation valence on aggregation kinetics of titanium dioxide nanoparticles. Environ. Sci. Technol. 43(5): 1354-1359.

Fujishima A, Honda K. 1972. Electrochemical photolysis of water at a semiconductor electrode. Nature. 238: 37-38.

Fujishima A, Rao TN, Tryk DA. 2000. Titanium dioxide photocatalysis. J. Photochem. Photobiol., C. Photochem. Rev. 1: 1-21.

Galley E, Fardell NA. 1997. Sunscreen with coated microfine particles. United States Patent, number $5,609,852$.

Galloway T, Lewis C, Dolciotti I, Johnston BD, Moger J, Regoli F. 2010. Sublethal toxicity of nano-titanium dioxide and carbon nanotubes in a sediment dwelling marine polychaete. Environ. Pollut. 158: 1748-1755.

Golanoski KS, Fang S, Del Vecchio R, Blough NV. 2012. Investigating the mechanism of phenol photooxidation by humic substances. Environ. Sci and Technol. 46(7): 3912-3920.

Gottschalk F, Ort C, Scholz RW, Nowack B. 2011. Engineered nanomaterials in rivers exposure scenarios for Switzerland at high spatial and temporal resolution. Environ. Pollut. 159: 3439-3445.

Griffitt RJ, Luo J, Gao J, Bonzonga J-C, Barber DS. 2008. Effects of particle composition and species on toxicity of metallic nanomaterials in aquatic organisms. Environ. Toxicol. and Chem. 27: $1972-1978$.

Guzman KAD, Finnegan MP, Banfield JF. 2006. Influence of surface potential on aggregation and transport of titania nanoparticles. Environ. Sci. Technol. 40: 7688-7693.

Häder D-P, Kumar HD, Smith RC, Worrest RC. 2007. Effects of solar UV radiation on aquatic ecosystems and interactions with climate change. Photochem. and Photobiol. Sci. 6: 267-285.

Hill PS. 1998. Controls on floc size in the sea. Oceanography. 11: 13-18. 
Hoffman MR, Martin ST, Choi W, Bahnemann DW. 1995. Environmental applications of semiconductor photocatalysis. Chemical Reviews. 95: 69-96.

Hund-Rinke K, Simon M. 2006. Ecotoxic effect of photocatalytic active nanoparticles $\left(\mathrm{TiO}_{2}\right)$ on algae and daphnids. Environ. Sci. \& Pollut. Res. 13: 225-232.

Jackson GA. 1990. A model of the formation of marine algal flocs by physical coagulation processes. Deep-Sea Res. 37: 1197-1211.

Johnson RL, Johnson GO, Nurmi JT, Tratnyek PG. 2009. Natural organic matter enhanced motility of nano zerovalent iron. Environ. Sci and Technol. 43(14): 5455-5460.

Johnson BD, Gilbert SL, Khan B, Carroll DL, Ringwood AH. 2015. Cellular responses of eastern oysters, Crassostrea virginica, to titanium dioxide nanoparticles. Mar. Environ. Res. 111: 135-143.

Johnston HJ, Hutchison GR, Christensen FM, Peters S, Hankin S, Stone V. 2009. Identification of the mechanisms that drive the toxicity of $\mathrm{TiO}_{2}$ particulates: the contribution of physicochemical characteristics. Particle and Fibre Toxicol. 6(33): 1-27.

Kiørboe T. 2001. Formation and fate of marine snow: small-scale processes with large-scale implications. Scientia marina. 65(S2): 57-71.

Kiørboe T, Tang K, Grossart H-P, Ploug H. 2003. Dynamics of microbial communities on marine snow aggregates: colonization, growth, detachment, and grazing mortality of attached bactria. Appl. Environ. Microbiol. 69: 3036-3047.

Kirk JTO. 1994. Light and Photosynthesis in Aquatic Ecosystems: 2nd Edition. Cambridge University Press: Cambridge, UK.

Lee BC, Kim KT, Cho JG, Lee JW, Ryu TK, Yoon JH, Lee SH, Duong CN, Eom IC, Kim PJ, Choi KH. 2012. Oxidative stress in juvenile common carp (Cyprinus carpio) exposed to TiO2 nanoparticles. Mol. Cell. Toxicol. 8: 357-366.

Lee W-M, An Y-J. 2013. Effects of zinc oxide and titanium dioxide nanoparticles on green algae under visible, UVA, and UVB irradiations: no evidence of enhanced algal toxicity under UV preirradiation. Chemosphere 91: 536-544.

Li F, Liang Z, Zheng X, Zhao W, Wu M, Wang Z. 2015. Toxicity of nano-TiO2 on algae and the site of reactive oxygen species production. Aquat. Toxicol. 158: 1-13.

Li Y-L, Ishigaki T. 2003. Core-shell micron-scale composites of titanium oxide and carbide formed through controlled thermal-plasma oxidation. Chem. Phys. Letters. 367: 561-565.

Li S, Wallis LK, Diamond SA, Ma H, Hoff DJ. 2014a. Species sensitivity and dependence on exposure conditions impacting the phototoxicity of $\mathrm{TiO} 2$ nanoparticles to benthic organisms. Environ. Toxicol. and Chem. 33(7): 1563-1569.

Li S, Wallis LK, Ma H, Diamond SA. 2014b. Phototoxicity of TiO2 nanoparticles to a freshwater benthic amphipod: are benthic systems at risk? Sci. of the Total Environ. 466-467: 800-808. 

organic matter on particle behavior and phototoxicity of titanium dioxide nanoparticles. Sci of the Total Environ. 542 (Part A): 324-333.

Lu Z. 2006. Optical absorption of pure water in the blue and ultraviolet. Texas A\&M University, Dissertation. 115 pp.

Lyons MM. 2008. The role of marine aggregates in the ecological epizootiology of Quahog Parasite X (QPX) disease in northern quahogs (= hard clams) Mercenaria mercenaria. University of Connecticut, Storrs, CT, Dissertation. 283 pp.

Lyons MM, Lau Y-T, Carden WE, Ward JE, Roberts SB, Smolowitz R, Vallino J, Allam B. 2007. Characteristics of marine aggregates in shallow-water ecosystems: implications for disease ecology. EcoHealth. 4(4): 406-420.

Ma H, Brennan A, Diamond SA. 2012. Phototoxicity of TiO2 nanoparticles under solar radiation to two aquatic species: Daphnia magna and Japanese medaka. Environ. Toxicol. and Chem. 31 (7): 1621-1629.

Ma H, Williams PL, Diamond SA. 2013. Ecotoxicity of manufactured ZnO nanoparticles - A review. Env. Pollut. 172: 76-85.

Maness P-C, Smolinski S, Blake DM, Huang Z, Wolfrum EJ, Jacoby WA. 1999. Bactericidal activity of photocatalytic TiO2 reaction: toward an understanding of its killing mechanism. Appl. Env. Microbiol. 65(9): 4094-4098.

Mansfield CM, Alloy MM, Hamilton J, Verbeck GF, Newton K, Klaine SJ, Roberts AP. 2015. Photo-induced toxicity of titanium dioxide nanoparticles to Daphnia magna under natural sunlight. Chemosphere. 120: 206-210.

Marcone GPS, Oliveira ÁC, Alemida G, Umbuzeiro GA, Jardim WF. 2012. Ecotoxicity of TiO2 to Daphnia similis under irradiation. J. of Haz. Mat. 211-212: 436-442.

Matsuo S, Anraku Y, Yamada S, Honjo T, Matsuo T, Wakita H. 2001. Effects of photocatalytic reactions on marine plankton: titanium dioxide powder as catalyst on the body surface. J. Environ. Sci. Health. A36: 1419-1425.

McPherson ML, Hill VJ, Zimmerman RC, Dierssen HM. 2011. The optical properties of Greater Florida Bay: Implications for seagrass abundance. Estuaries and Coasts. 34: 1150.

Mehmet A, Demir V, Adiguzel R, Arslan Z. 2013. Bioaccumulation, subacute toxicity, and tissue distribution of engineered titanium dioxide nanoparticles in goldfish (Carassius auratus). J. of Nanomaterials. ID 460518: 1-6.

Metzler DM, Li M, Erdem A, Huang CP. 2011. Responses of algae to photocatalytic nano-TiO2 particles with an emphasis on the effect of particle size. Chem. Eng. J. 170: 538-546.

Miller RJ, Bennett S, Keller AA, Pease S, Lenihan HS. 2012. TiO2 nanoparticles are phototoxic to marine phytoplankton. PLoS ONE. 7(1): e30321, 1-7. 

Photobiol. A. Chem. 108: 1-35.

Mills A, Lee S-J. 2002. A web-based overview of semiconductor photochemistry-based current commercial applications. J. Photochem. Photobiol., A. Chem. 152: 233-247.

Mobley CD. 1994. Light and Water: Radiative Transfer in Natural Waters. Academic Press.

Moore MN. 2006. Do nanoparticles present ecotoxicological risks for the health of the aquatic environment? Environmental International. 32: 967-976.

Morel A. 1988. Optical modeling of the upper ocean in relation to its biogenous matter content (case I waters). J. of Geophys. Res. 93: 10749-10768.

Morel A, Ahn YH. 1990. Optical efficiency factors of free-living marine bacteria: Influence of bacterioplankton upon the optical properties and particulate organic carbon in oceanic waters. J. Mar. Res. 48: 145-175.

Morel A, Gentili B, Claustre H, Babin M, Bricaud A, Ras J, Tièche F. 2007. Optical properties of the 'clearest' natural waters. Limnol. Oceanogr. 52: 217-229.

Mueller N, Nowack B. 2008. Exposure modeling of engineered nanoparticles in the environment. Environmental Science and Technology. 42: 4447-4453.

Murakami Y, Endo K, Ohta I, Nosaka AY, Nosaka Y. 2007. Can OH radicals diffuse from the UV-irradiated photocatalytic $\mathrm{TiO}_{2}$ surfaces? Laser-induced-fluorescence study. J. Phys. Chem. C. 111: 11339-11346.

Nakano H, Hasuike N, Kisoda K, Nishio K, Isshiki T, Harima H. 2009. Synthesis of $\mathrm{TiO}_{2}$ nanocrystals controlled by means of the size of magnetic elements and the level of doping with them. J. Phys.: Condens. Matter. 21: 1-5.

Nam D-H, Lee B-c, Eom I-c, Kim P, Yeo M-K. 2014. Uptake and bioaccumulation of titaniumand silver-nanoparticles in aquatic ecosystems. Mol. Cell. Toxicol. 10: 9-17.

Navarrro E, Baun A, Behra R, Hartmann NB, Filser J, Miao A-J, Quigg A, Santschi PH, Sigg L. 2008. Environmental behavior and ecotoxicity of engineered nanoparticles to algae, plants, and fungi. Ecotoxicol. 17: 372-386.

NOAA CoastWatch [Internet]. [cited 2016 July 27]. Available from: eastcoast.coastwatch.noaa.gov.

Nurmi JT, Tratnyek PG. 2002. Electrochemical properties of natural organic matter (NOM), fractions of NOM, and model biogeochemical electron shuttles. Environ. Sci and Technol. 36(4): 617-624.

Petosa AR, Jaisi DP, Quevedo IR, Elimelech M, Tufenkji N. 2010. Aggregation and deposition of engineered nanomaterials in aquatic environments: role of physicochemical interactions. Environ. Sci. Technol. 44: 6532-6549. 
Pope RM, Fry ES. 1997. Absorption spectrum (380-700 nm) of pure water. II. Integrating cavity measurements. Applied Optics. 36(33): 8710-8723.

Rai VR, Bai AJ. 2011. Nanoparticles and their potential application as antimicrobials. Science Against Microbial Pathogens: Communicating Current Research and Technological Advances Vol. 1. Mendez-Vilas A. Ed: Formatex Research Center: Badajoz, Spain. pp. 691.

Reeves JF, Davies SJ, Dodd NJF, Jha AN. 2008. Hydroxyl radicals are associated with titanium dioxide nanoparticle-induced cytotoxicity and oxidative DNA damage in fish cells. Mut. Res. 640: $113-122$.

Rincón AG, Pulgarin C. 2003. Photocatalytical inactivation of E. coli: effect of (continuousintermittent) light intensity and of (suspended-fixed) $\mathrm{TiO}_{2}$ concentration. Appl. Catalysis B: Environ. 44: 263-284.

Robichaud CO, Uyar AE, Darby MR, Zucker LG, Wiesner MR. 2009. Estimates of upper bounds and trends in nano- $\mathrm{TiO}_{2}$ production as a basis for exposure assessment. Environ. Sci. Technol. 43: 4227-4233.

Roy S, Sathyendranath S, Platt T. 2011. Retrieval of phytoplankton size from bio-optical measurements: theory and applications. J. R. Soc. Interface. 8: 650-660.

Rupert CS, Goodgal SH, Herriott RM. 1958. Photoreactivation in vitro of ultraviolet inactivated hemophilus influenza transforming factor. J. Gen. Physiol. 41: 451-470.

Russell BJ, Dierssen HM. 2015. Use of hyperspectral imagery to assess cryptic color matching in Sargassum associated crabs. PLoS ONE. 10(9): 1-26.

Schultz AG, Boyle D, Chamot D, Ong KJ, Wilkinson KJ, McGeer JC, Sunahara G, Goss GG. 2014. Aquatic toxicity of manufactured nanomaterials: challenges and recommendations for future toxicity testing. Environ. Chem. 11: 207-226.

Scown TM, Aerle R van, Tyler CR. 2010. Review: do engineered nanoparticles pose a significant threat to the aquatic environment? Crit. Rev. in Toxicol. 40(7): 653-670.

Serpone N, Lawless D, Khairutdinov R, Pelizzetti E. 1995. Subnanosecond relaxation dynamics in TiO2 colloidal sols (particle sizes $\mathrm{Rp}=1.0-13.4 \mathrm{~nm}$ ). Relevance to heterogeneous photocatalysis. J. Phys. Chem. 99: 16655-16661.

Sharma VK. 2009. Aggregation and toxicity of titanium dioxide nanoparticles in aquatic environment - A review. J. Environ. Sci. Health Part A. 44: 1485-1495.

Shih Y-H, Liu W-S, Su Y-F. 2012. Aggregation of stabilized $\mathrm{TiO}_{2}$ nanoparticle suspensions in the presence of inorganic ions. Env. Tox. Chem. 31: 1693-1698.

Shirley R, Kraft M, Inderwildi O. 2010. Electronic and optical properties of aluminum doped anatase and rutile $\mathrm{TiO}_{2}$ from ab initio calculations. Physical Review B. 81(7): 075111.

Sillanpää M, Paunu TM, Sainio P. 2011. Aggregation and deposition of engineered $\mathrm{TiO}_{2}$ nanoparticles in natural fresh and brackish waters. J. Phys. Conf. Ser. 304: 1-8. 
Simic MG, Jovanovic SV. 1986. Free radical mechanisms of DNA base damage. Mech. of DNA Damage and Repair. 189: 39-49.

Simon M, Grossart H, Schweitzer B, Ploug H. 2002. Microbial ecology of organic aggregates in aquatic ecosystems. Aquat. Microbiol. Ecol. 28: 175-211.

Smith RC, Baker KS. 1981. Optical properties of the clearest natural waters (200-800 nm). Applied Optics. 20(2): 177-184.

Sinha RP, Häder D-P. 2002. UV-induced DNA damage and repair: a review. Photochem. and Photobiol. Sci. 1: 225-236.

Stafford U, Gray KA, Kamat PV. 1997. Photocatalytic degradation of 4-chlorophenol: the effects of varying $\mathrm{TiO} 2$ concentrations and light wavelength. J. Catalysis 167: 25-32.

Sun H, Zhang X, Niu Q, Chen Y, Crittenden JC. 2007. Enhanced accumulation of arsenate in carp in the presence of titanium dioxide nanoparticles. Water, Air, and Soil Pollut. 178: 245-254.

Tatsuma T, Tachibana S-i, Fujishima A. 2001. Remote oxidation of organic compounds by UVirradiated TiO2 via the gas phase. J. Phys. Chem. B. 105: 6987-6992.

Tatsuma T, Tachibana S-i, Miwa T, Tryk DA, Fujishima A. 1999. Remote bleaching of methylene blue by UV-irradiated TiO2 in the gas phase. J. Phys. Chem. B. 103: 8033-8035.

Torrey J. 2014. TiO2 cement for green construction. U.S. Dept. of Interior, technical memorandum. MERL-2014-84.

Twardoski MS, Boss E, Sullivan JM, Donaghay PL. 2004. Modeling the spectral shape of absorption by chromophoric dissolved organic matter. Mar. Chem. 89: 69-88.

Vevers WF, Jha AN. 2008. Genotoxic and cytotoxic potential of titanium dioxide nanoparticles on fish cells in vitro. Ecotoxicol. 17: 410-420.

Vincent WF, Kumagai M, Belzile C, Ishikawa K, Hayakawa K. 2001. Effects of seston on ultraviolet attenuation in Lake Biwa. Limnol. 2: 179-184.

Waite AM, Safi KA, Hall JA, Nodder SD. 2000. Mass sedimentation of picoplankton embedded in organic aggregates. Limnol. Oceanogr. 45: 87-97.

Wang J, Hu M, Li Q, Li J, Lin D, Lu W. 2014. Immune toxicity of TiO2 under hypoxia in the green-lipped mussel Perna viridis based on flow cytometric analysis of hemocyte parameters. Sci. of the Tot. Environ. 470-471: 791-799.

Warheit DB, Hoke RA, Finlay C, Donner EM, Reed KL, Sayes CM. 2007. Development of a base set of toxicity tests using ultrafine $\mathrm{TiO} 2$ particles as a component of nanoparticle risk management. Toxicol. Letters. 171: 99-110.

Weir A, Westerhoff P, Fabricius L, Hristovski K, Goetz N von. 2012. Titanium dioxide nanoparticles in food and personal care products. Environ. Sci. Technol. 46: 2242-2250. 
Wold A. 1993. Photocatalytic properties of titanium dioxide (TiO2). Chem. Mater. 5(3): 280283.

Wozniak B, Dera J. 2007. Light Absorption in Sea Water; Springer: New York, U.S.

Xie B, Xu Z, Gu W, Li Q. 2008. Impact of Natural Organic Matter on the Physicochemical Properties of Aqueous $\mathrm{C}_{60}$ Nanoparticles. Environ. Sci. Technol. 42: 2853-2859.

Yang K, Lin D, Xing B. 2009. Interactions of humic acid with nanosized inorganic oxides. Langmuir. 25(6): 3571-3576.

Yang SP, Bar-Ilan O, Peterson RE, Heideman W, Hamers RJ, Pedersen JA. 2013. Influence of humic acid on titanium dioxide nanoparticle toxicity to developing zebrafish. Environ. Sci and Technol. 47: 4718-4725.

Yang T-S, Shiu C-B, Wong M-S. 2004. Structure and hydrophilicity of titanium oxide films prepared by electron beam evaporation. Surf. Sci. 548: 75-82.

Zhang X, Sun H, Zhang Z, Niu Q, Chen Y, Cittenden JC. 2007. Enhanced bioaccumulation of cadmium in carp in the presence of titanium dioxide nanoparticles. Chemosphere. 67: 160-166. 
Table 1. Summary of photocatalytic studies on aquatic organisms using $\mathrm{TiO}_{2} \mathrm{NP}$.

\begin{tabular}{|c|c|c|c|c|c|c|c|}
\hline Publication & NP Type & Light intensity & Light duration & Experimental duration & [NP] & Organism & Effect \\
\hline Amiano et al. 2012 & $\begin{array}{l}\text { P25 } \\
\text { P25 }\end{array}$ & $\begin{array}{l}\text { UVA }(0.56 \mathrm{~mW} / \mathrm{cm} 2) \\
\text { SSR. } 15-4.5 \mathrm{~mW} / \mathrm{cm}^{2}\end{array}$ & 16 hours UVA : 8 hours dark & 2 days & $1-10.5 \mathrm{mg} / \mathrm{L}$ & Daphnia magna & increased immobilization; increased toxicity with UVA \\
\hline Faria et al 2014 & P25 & SSR; $1.5-4.5 \mathrm{~mW} / \mathrm{cm} 2$ & 4 hours & 6 days & $1 \mathrm{mg} / \mathrm{mL}$ & Danio rerio embryos & ROS production/oxidative stress \\
\hline Farkas et al. 2015 & Anatase/rutile & Sunny conditions at Lake Erken (Sweden) & summer day time hours & 5 days & $15-1000 \mu \mathrm{g} / \mathrm{L}$ & freshwater bacteria & UV/PAR did not enhance toxicity \\
\hline Johnson et al. 2015 & unreported & PAR; 386--694 uE/m2/sec & 4 hours & 24 hours & $50 \mu \mathrm{g} / \mathrm{L}$ & Crassostrea virginica hepatopancreas tissue & Decreased lysosomal stability \\
\hline Lee \& An 2013 & P25 & UVA (316-400 nm); UVB (281-315 nm) & 20 min pre-irradiation & 3 days & $0.5-10 \mathrm{mg} / \mathrm{L}$ & green algae $P$ seudokirchneriella subcapitata & suppressed growth \\
\hline Li et al. 2014(a) & P25 & $\mathrm{SSR} ; 0.94 \mathrm{~mW} / \mathrm{cm} 2$ & 4 hours & 2 days & $20 \mathrm{mg} / \mathrm{L}$ & benthics: H. azteca, L. variegatus \& C. dilutus & Significant mortality \\
\hline Li et al. 2014(b) & P25 & $\mathrm{SSR} ; 0.22 \mathrm{~mW} / \mathrm{cm} 2$ & 4 hours & $2-4$ days & $100 \mathrm{mg} / \mathrm{L}$ & benthic amphipod, Hyalella azteca & 21-fold increase in toxicity with SSR \\
\hline Ma et al. 2012 & P25 & SSR; UV $1.7 \mathrm{~mW} / \mathrm{cm} 2$ & 4 hours & 2 days & $2 \mathrm{~g} / \mathrm{L}$ & Daphnia magna & LC50 $29.8 \mathrm{ug} / 1$ \\
\hline -.-- & P25 & $\mathrm{SSR} ; \mathrm{UV} 1.7 \mathrm{~mW} / \mathrm{cm} 2$ & 4 hours & 4 days & $2 \mathrm{~g} / \mathrm{L}$ & Japanese medaka fish larvae & LC50 $2.2 \mathrm{mg} / 1$ \\
\hline Mansfield et al. 2015 & Anatase & Natural sunlight (avg. $4.7 \mathrm{~mW} / \mathrm{cm} 2$ ) & summer day time hours & 8 hours & $20 \& 200 \mathrm{mg} / \mathrm{L}$ & Daphnia magna & significant mortality \\
\hline Metzler et al. 2011 & P25 & 1764 lux & 4 days & 4 days & $10-1000 \mathrm{mg} / \mathrm{L}$ & green algae Pseudokirchneriella subcapitata & suppressed growth; NP adhesion to surface \\
\hline Marcone et al. 2012 & Anatase \& rutile & UV-vis fluorescent lamp & 2 days & 2 days & $100 \mathrm{mg} / \mathrm{L}$ & Daphnia similis & Non-toxic \\
\hline Miller et al. 2012 & Anatase/rutile & UV-vis fluoressent lamp & 14 hour light : 10 hour dark & 4 days & $1-7 \mathrm{mg} / \mathrm{L}$ & marine phytoplankton & suppressed growth; NP adhesion to surface \\
\hline Reeves et al. 2008 & Anatase & UVA $(340-420 \mathrm{~nm})$ & 2 hours & 2 hours & $1000 \mu \mathrm{g} / \mathrm{mL}$ & goldfish skin cells & lowered cell viability \\
\hline Vevers and Jha 2008 & Rutile/anatase & $0.15-0.3 \mathrm{~mW} / \mathrm{cm} 2 ;$ UVA $(340-420 \mathrm{~nm})$ & 20 - 40 minutes & 4 hours -2 days & $500 \mu \mathrm{g} / \mathrm{mL}$ & rainbow trout gonadal tissue & cytotoxicity; DNA strand breaks \\
\hline
\end{tabular}




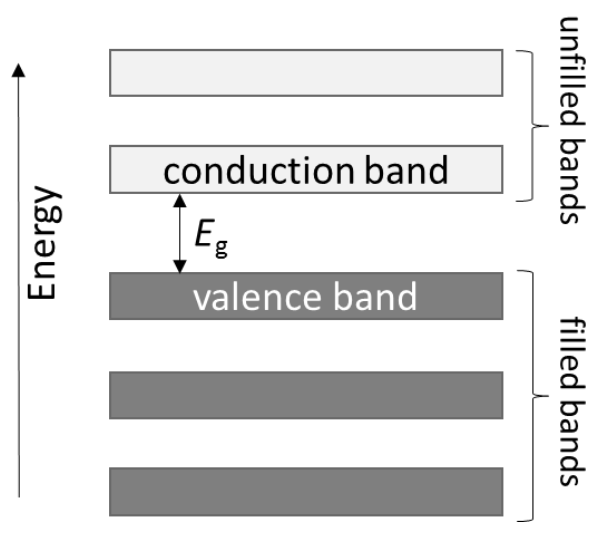

Figure 1.

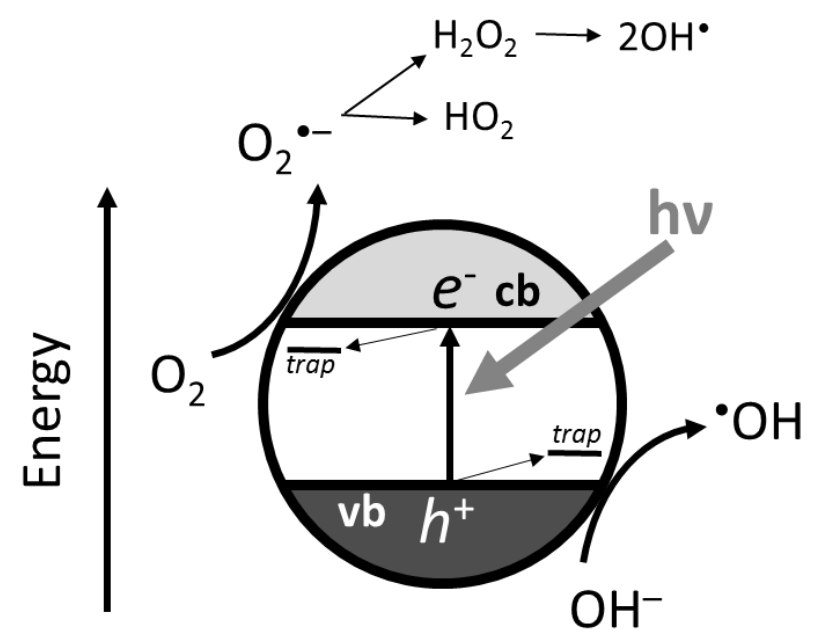

Figure 2. 

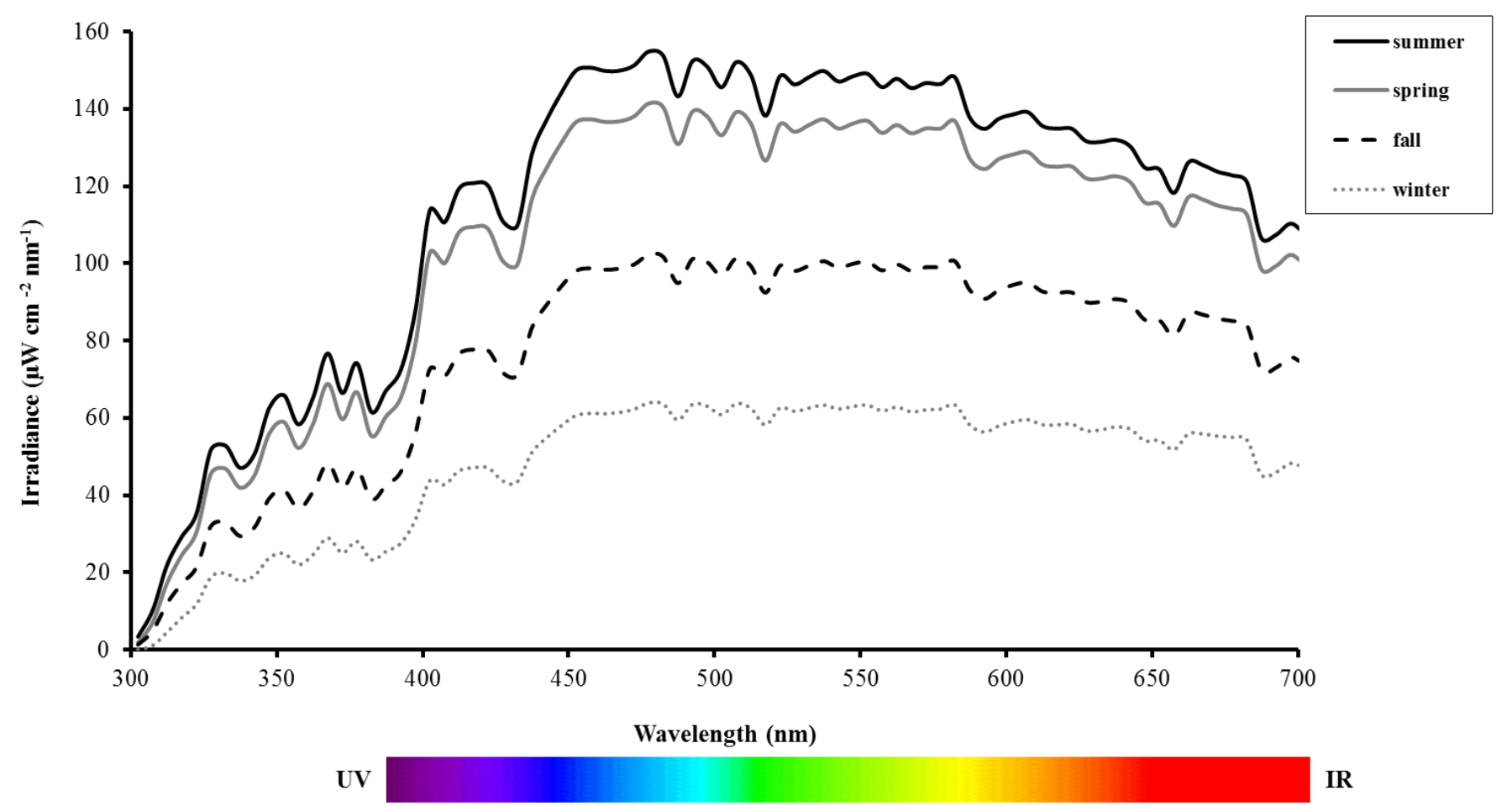

Figure 3.

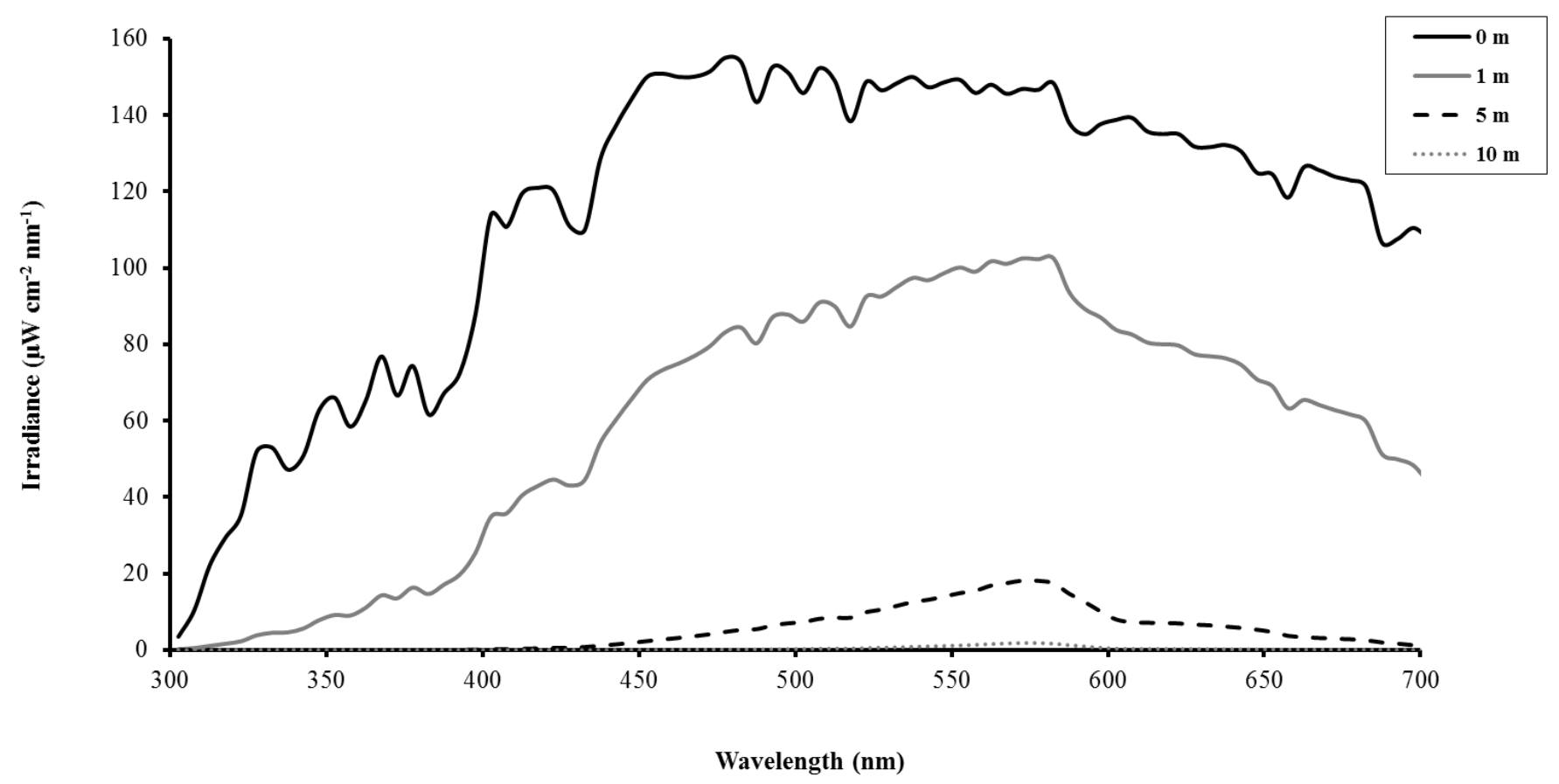

Figure 4. 


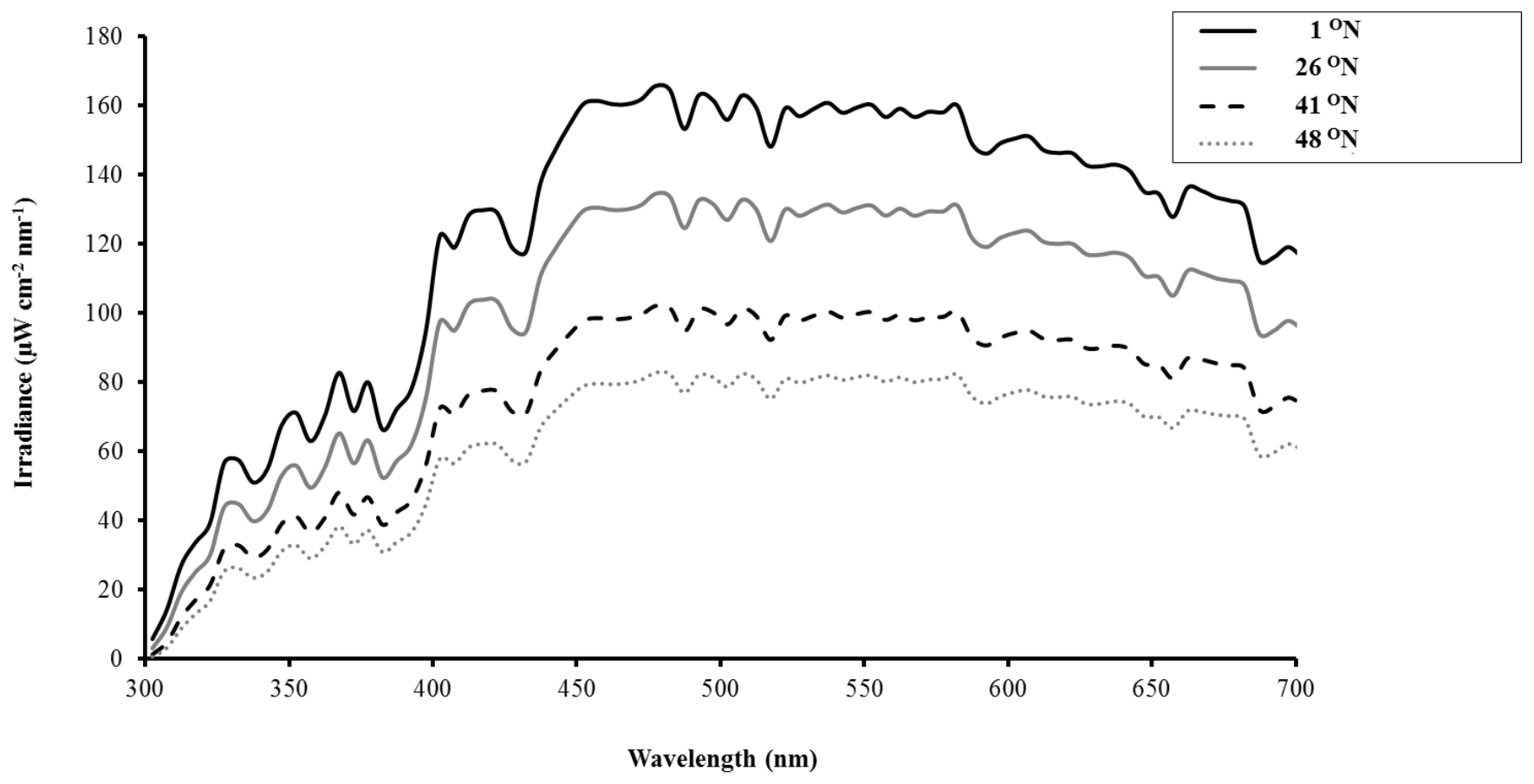

Figure 5. 
Figure 1. Electronic structure of a semiconductor, with unfilled conduction band and filled valence band separated by the bandgap energy Eg.

Figure 2. Key reactions of irradiated $\mathrm{TiO}_{2}$ including (top left) reduction of $\mathrm{O}_{2}$ by a conduction band electron, giving rise to activated oxygen species, and (bottom right) oxidation of hydroxide by a valence band hole, forming a hydroxyl radical.

Figure 3. Seasonal variation of irradiance spectrum from Hydrolight simulations at ocean surface $\mathrm{E}_{\mathrm{d}}\left(0^{-}\right)$in middle of Long Island Sound $\left(41^{\circ} \mathrm{N} / 72{ }^{\circ} \mathrm{W}\right)$. Water parameters included chlorophyll $a$ $\left(0.1,5,1\right.$ and $7 \mathrm{mg} / \mathrm{m}^{3}$ for winter - fall, respectively; data from NOAA CoastWatch 2016), CDOM (0.3 $\mathrm{m}^{-1}$; Kirk 1994), and total suspended solids (TSS; 3 g/L; NOAA CoastWatch 2016). Color bar corresponds to PAR wavelengths and adjacent UV and infra-red (IR) boundaries are indicated.

Figure 4. Variation in irradiance spectrum from Hydrolight simulations at depths $0,1,5$ and 10 $\mathrm{m}$ in Long Island Sound $\left(41^{\circ} \mathrm{N} / 72{ }^{\circ} \mathrm{W}\right)$ during summer. Water parameters included chlorophyll $a$ $\left(1 \mathrm{mg} / \mathrm{m}^{3}\right.$; data from NOAA CoastWatch 2016), CDOM (0.3 m ${ }^{-1}$; Kirk 1994), and TSS (3 g/L; NOAA CoastWatch 2016).

Figure 5. Irradiance spectrum from Hydrolight simulations at ocean surface $E_{d}\left(0^{-}\right)$during fall at four different latitudes $\left(1,26,41\right.$ and $\left.48^{\circ} \mathrm{N}\right)$. Water parameters included chlorophyll $a\left(7 \mathrm{mg} / \mathrm{m}^{3}\right.$; data from NOAA CoastWatch 2016), CDOM (0.3 $\mathrm{m}^{-1}$; Kirk 1994), and TSS (3 g/L; NOAA CoastWatch 2016). 